is at least doubtful whether the existence of such organized knowledge thirty years ago could have spared the world much of the devastation of unemployment; or whether it is possible to plan in advance when conditions are rapidly changing. Apart from the difficulty of predicting with any accuracy the effect of scientific discoveries on society, the wise use of knowledge involved in planning requires not merely the use of existing knowledge to avoid mistakes committed in the past, but also adaptability, an enlightened opportunism and a readiness to examine all matters in the spirit and method of science. It is, however, a hopeful sign that leaders of scientific thought are to an increasing extent concerning themselves with the consequences of the application of scientific discoveries. Organizations such as the Scottish Development Council and the National Trust, cited by Sir James, already exist for the wise use or conservation of our national resources, and they deserve the support of all who are in any measure equipped to guide opinion and direct progress.

\section{Social Economics in the University of Manchester}

ThE Council of the University of Manchester has announced its decision to revive the second chair in the Faculty of Commerce and Administration, which has been in abeyance since 1932, with the title of "Chair of Social Economics". Mr. John Jewkes, who has been in charge of the Economics Research Section of the Faculty, which has been responsible for such important investigations as the industrial surveys of Lancashire and also Cumberland and Furness, undertaken for the Board of Trade, and the study of juvenile unemployment, has been elected to the chair as from September next. The duties will include the conduct of research and supervision of the work in the Economies Research Section, the creation of which was a new development in Great Britain in the organization of economic research within a university. It has now passed the experimental stage, and Mr. Jewkes's appointment is a recognition of it as an integral and permanent part of the work of the Department of Economics at the University of Manchester. Among a number of important inquiries which are in hand may be mentioned a study of the case histories of 2,000 juveniles in Lancashire who left school at Easter 1934 ; a study of the location of British industry, the changes proceeding and the forces behind them; a re-assessment of the industrial situation in Lancashire, being carried out at the invitation of the Lancashire Industrial Development Council ; and a study of the systems of wage payment and labour conditions in the Lancashire cotton-weaving industry.

\section{Manganese and Plant Growth}

Manganese is now recognized as an essential element for normal plant growth, and most soils contain sufficient of it in an available form to supply the needs of all vegetation. There are certain soils, however, mainly reclaimed swamp soils and soils with a very high calcium carbonate content, in which manganese is either not present in sufficient quantity, or not in an available enough form, to support the growth of certain crops. Characteristic diseases then result, of which the best known are the grey speck disease of oats, a disease of beet in Holland, chlorosis of spinach on Long Island and diseases of tomatoes and other crops on the Everglade soils of Florida, although in the last case deficiency of copper appears to be concerned as well as of manganese. The availability of the manganese in the soil is influenced to some extent by weather conditions and by cultural practices. In general, dry conditions aggravate the diseases, and also manurial treatments, such as liming, which tend to make the soil more alkaline. In Denmark a formula is now used, known as the 'manganese value' (Steenbjerg, Trans. Third Int. Congr. Soil Sci. Oxford, 1935), which is based on a determination of the exchangeable manganese by leaching with magnesium nitrate, and on a factor which is a measure of the energy displayed by the soil colloids in keeping the exchangeable manganese. It is advocated that the manganese value of a soil should always be determined before liming, especially in the case of sandy soils, so that a calculation can be made of the largest allowable increase in $p H$ which would not entail danger of grey speck disease. In the same report, Gerretsen claims that the symp. toms of manganese deficiency are largely the result of the absorption of toxic products from bacteria which multiply more profusely on the roots of manganese-deficient plants.

\section{Eastern Frontiers of the Roman Empire}

SIR AUREL Stern has made an offer to the authorities concerned to make a detailed survey of that part of the eastern frontier of the ancient Roman Empire which lies within Transjordania and Iraq. It will be necessary that a great part of this survey should be carried out from the air, as many of the sites are situated in the desert, and can be located only by this method. The proposal has the support of the British Academy and the Society of Antiquaries of London. It will form part of the scheme for the complete survey of the Roman Empire on a scale of $\mathrm{I}: 1,000,000$, for which the British Ordnance Survey has already accepted its share of responsibility. The French have now completed the survey of that part of the frontier within the mandated territory of Syria. The survey was made by the French Air Force acting in conjunction with the Académie des Inscriptions et Lettres, and records observations of ancient roads, forts and defensive posts, as well as water supply. It is proposed that similar observations should be made in the survey projected by Sir Aurel Stein.

\section{Racial Elements in Sumerian Art}

Archalologists at times may seem over-bold in attributing racial values to the terms of their cultural analyses, although the practice frequently has much to be said in its favour, when it is followed, with due reservation, as a convenient form of shorthand while a question of origins is still in suspense. Sir 